\title{
LEPISOSTEIFORM FISH (HOLOSTEI) GANOID SCALES FROM THE MIDDLE JURASSIC DEPOSITS OF UKRAINE
}

\author{
O. M. Kovalchuk ${ }^{1}$, G.V. Anfimova ${ }^{2}$ \\ National Museum of Natural History NAS of Ukraine, \\ B. Khmelnytsky st., 15, Kyiv, 01030 Ukraine \\ E-mail: ${ }^{1}$ biologiest@ukr.net, ${ }^{2}$ anfimova77@ukr.net
}

Lepisosteiform Fish (Holostei) Ganoid Scales from the Middle Jurassic Deposits of Ukraine. Kovalchuk, O. M., Anfimova, G. V. - Gars (Lepisosteiformes) flourished in epicontinental seas throughout the world during the second half of Mesozoic and early Cenozoic. Cretaceous and Paleogene remains of these fishes are common in Europe while their Jurassic fossils are still relatively scarce. Here we re-describe in detail a series of ganoid scales from the latest Middle Jurassic (Callovian) deposits of Pekari (Cherkasy Region, Ukraine). These fossils were identified by Professor O. S. Rogovich in 1861 as those that belong to Lepidotus mantellii and L. fittoni. The referral of these scales to a certain species should be considered with caution because the described material lacks characters sufficient for identification it even to the genus or family. We consider to identify these fossils as Lepisosteiformes gen. et sp. indet. An overview of currently known Jurassic occurrences of lepisosteiform fishes is also presented in the paper. Key words: Lepisosteiformes, museum collection, morphology, Callovian, Europe.

\section{Introduction}

Order Lepisosteiformes is a small group of primitive neopterygian fishes comprising two families - Lepisosteidae with seven genera (only two of which - Atractosteus and Lepisosteus - remain extant), and †Obaichthyidae including two genera (Grande, 2010). In addition, seven extinct genera of lepisosteiform fishes ( $\dagger$ Ararilepidotes, $\uparrow$ Isanichthys, $\uparrow$ Lepidotes, $\uparrow$ Pliodetes, $\dagger$ Thaiichthys, and $\uparrow$ Scheenstia $)$ are indicated by incertae familiae (López-Arbarello, 2012). The current distribution of gars is restricted to North America, Central America and the Caribbean islands (Nelson et al., 2016). However, it was much wider during Mesozoic and early Cenozoic as evidenced by the presence of their fossils throughout the world (e. g. in South America, Africa, Europe and Asia; see Grande, 2010).

Lepisosteiform fishes appeared in the fossil record in the Early Jurassic and became diverse during the Late Jurassic and Early Cretaceous (López-Arbarello, 2012). However, little is known about the taxonomic composition and diversity of the Jurassic lepisosteiforms. Their remains in Europe are relatively scarce, but even if present, they are mostly unknown due to being "buried" in old natural history collections without a detailed description (Tretyak \& Chervonenko, 2016). 

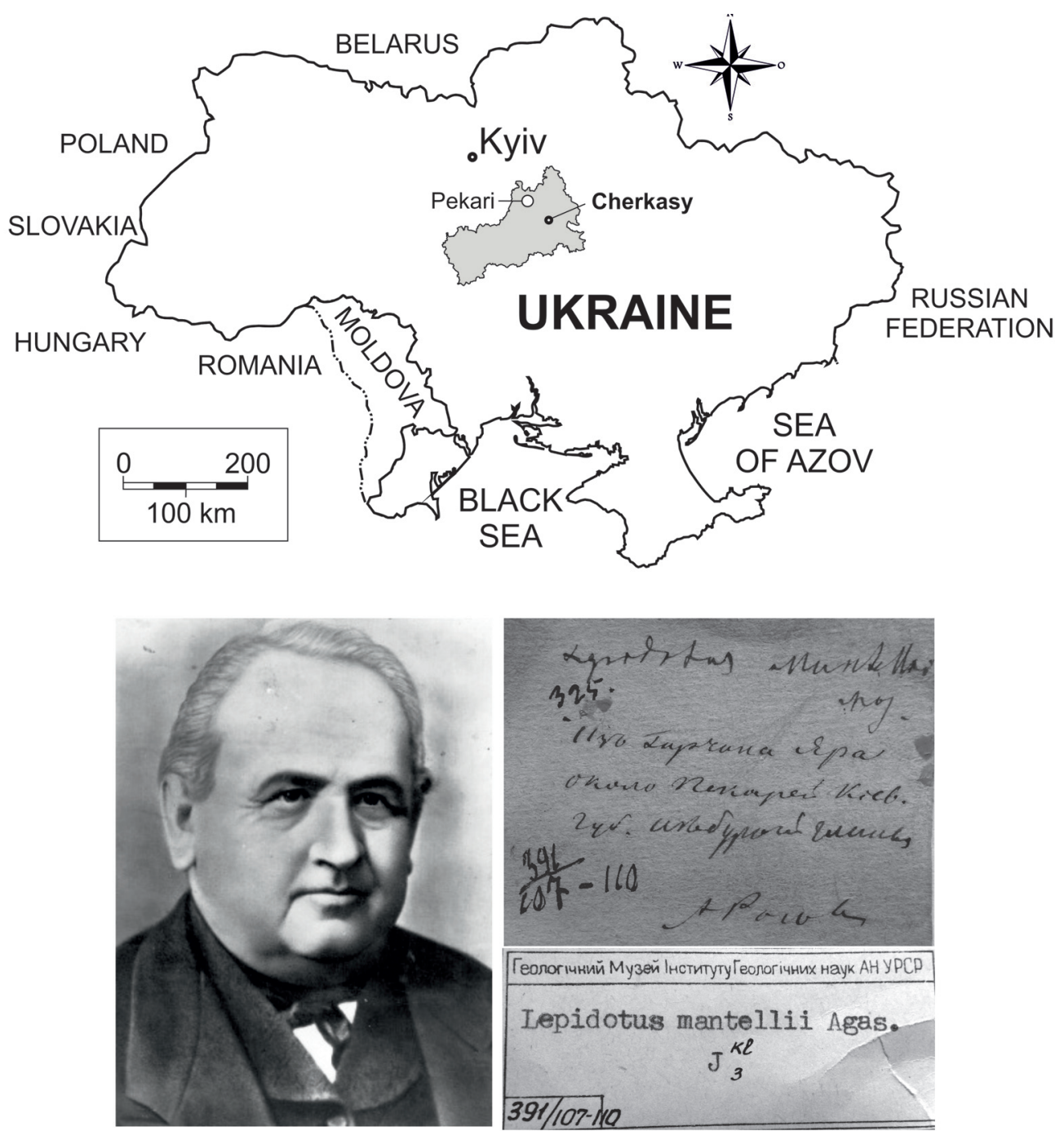

Fig. 1. Location of the Pekari fossil site on the map of Ukraine, the portrait of Professor O. S. Rogovich with the original (above) and additional labels (below) of the described material.

One of such finds is a series of ganoid scales briefly described by Rogovich (1861) from the Middle Jurassic deposits of Girchin quarry near Pekari, Cherkasy region, Ukraine (fig. 1). Rogovich (1861) assigned these scales to "Lepidotus Mantellii" and "Lepidotus Fittoni" based on their general similarity to scales of those species, which were previously described by Agassiz (1833-1844). The scales are "thin and thick, angular or completely rhomboidal in shape (depending on its position on the fish body)", and their outer surface is "smooth or yields folds and dashes" (Rogovich, 1861: 67-68).

The aim of our study is to describe in detail the morphology of ganoid scales from Pekari, re-interpret this finding in terms of current stratigraphy and place it into a broad biogeographical context.

Geological setting, additional fauna and age estimation

The section from which the studied scales and numerous shark teeth were collected consists of "diluvium, Eocene green-grey sand and conglomerate, Cretaceous green sandstone, clayey-lignite intercalations, and Jurassic clay exposed at the base" (Rogovich, 1861: 7).

Middle Jurassic deposits in the Kaniv dislocation area are represented by a series of light-brown and dark-grey clay referring to the ammonite zone Cadoceras (Paracadoceras) elatmae, formerly defined as Macrocephalites macrocephalus zone (Kiselev \& Ippolitov, 2011). A calcareous nannoplankton assemblage from these sediments was described by Matlaj (2016): Biscutum dubium, Lotharingius contractus, L. crucicentralis, Stephanolithon speciosum, Watznaueria barnesae, W. britannica, W. fossacincta, and W. manivitiae. These taxa represent the nannoplankton zone NJ12a/Ansulasphaera helvetica indicating the Early Callovian age (Matlaj, 
2016). Based on this study, marine conditions within the Kaniv dislocation area already existed in the Early Callovian.

The ammonite assemblage of the studied region is represented by Cadoceras (Paracadoceras) elatmae, Macrocephalites cf. verus, M. multicostatus/M. prosekensis, M. pavlowi, M. (Pleurocephalites) cf. terebratus, and Pseudocadoceras (Costacadoceras) mundum (Kiselev \& Ippolitov, 2011). This species list was supplemented by Gulyaev (2015) due to re-identification of some specimens from old museum collections and description of Bullatimorphites (Kheiraceras) bullatus. This taxon is common for the Paracadoceras elatmae biohorizon (Gulyaev, 2015), which is equal to the Cadoceras suevicum horizon in Germany (Mönnig, 2014). Gulyaev \& Ippolitov (2013) reported about the findings of numerous Early Callovian belemnite remains from Kaniv district, namely of Cylindroteuthis s. str., "Cylindroteuthis" kowalewi, Pachyteuthis s. str., and Communicobelus represented by different mophs.

\section{Material and methods}

The examined series of scales is stored in the Department of Geology of the National Museum of Natural History, National Academy of Sciences of Ukraine, Kyiv, Ukraine. The scales were identified using diagnostic features based on comparisons with extinct and modern taxa (deposited in Virginia Institute of Marine Science, USA, Hungarian Natural History Museum, Budapest, Hungary, and Babeş-Bolyai University Cluj-Napoca, Romania) as well as on data from the literature (Agassiz, 1833-1844; Grande, 2010; López-Arbarello, 2012; Alvarado-Ortega et al., 2014; Sweetman et al., 2014; Pouech et al., 2015). The taxonomic hierarchy follows López-Arbarello (2012), and Nelson et al. (2016). Morphological description is presented here according to Grande (2010), with reference to other publications (e.g., Kerr, 1952; Thompson \& McCune, 1984; Kumar et al., 2005; Alvarado-Ortega et al., 2014; Garbelli \& Tintori, 2015; Kyselevych \& Kovalchuk, 2019). The scales were measured by an electronic caliper, and photographed using a Leica M168C camera in Schmalhausen Institute of Zoology, National Academy of Sciences of Ukraine.

\section{Systematic paleontology \\ Class ACTINOPTERYGII Cope, 1887 sensu Rosen et al., 1981 \\ Subclass NEOPTERYGII Regan, 1923 sensu Nelson et al., 2016 \\ Infraclass HOLOSTEI Müller, 1844 sensu Grande, 2010 \\ Subdivision GINGLYMODI Cope, 1872 sensu Grande, 2010 \\ Order LEPISOSTEIFORMES Hay, 1929 sensu López-Arbarello, 2012}

\section{Lepisosteiformes gen. et sp. indet.}

Lepidotus mantellii Ag.: Rogovich, 1861, pp. 67-68; table IX, figs 27-34.

Lepidotus fittoni Ag.: Rogovich, 1861, p. 68; table IX, figs 35-39.

M a t e ri a l. Seven ganoid scales, Nos. 391/107a-d, 391/108-10.

L o cality and age. Pekari $\left(49^{\circ} 42^{\prime} \mathrm{N}, 31^{\circ} 33^{\prime} \mathrm{E}\right)$, Cherkasy Region, Ukraine; Middle Jurassic, Early Callovian $\left(\mathrm{J}_{2} \mathrm{kl}_{1}\right)$, ca. $166-165 \mathrm{Ma}$.

D e s c ription. Ganoid scales are represented by three morphotypes.

Morphotype 1 (specimen No. 391/109; fig. 2, $\mathrm{A}_{1}-\mathrm{A}_{2}$ ). The scale plate is elongated, smooth and narrow, irregularly rectangular in shape; its total length is $15.0 \mathrm{~mm}$, width $8.0 \mathrm{~mm}$. The thin ganoine layer covers the entire outer surface of the scale. Edges of the scale are smooth and rounded (posterodorsal angle is $103^{\circ}$, while the posteroventral angle equals $84^{\circ}$ ). The scale is the thickest along the ridge which is parallel to both its anterior and posterior edges. There is a weak serration (four small denticles with blunt tips) forming a shallow ridge on the dorsal edge, between the dorsal peg $(d p)$ and posterior margin of the scale. The anterodorsally oriented dorsal anterior process (dap) is strong, stout and sharp while the ventral anterior process (vap) is totally reduced. The space between the anterior processes is filled with a thin plate. The dorsal peg is shifted toward the dap base. Posterior edge of the scale is narrow; the ventral edge forms a long shallow ridge.

Morphotype 2 (specimens No. 391/107a, fig. 2, $\mathrm{B}_{1}-\mathrm{B}_{2}$; No. 391/107b, fig. 2, $\mathrm{C}_{1}-\mathrm{C}_{2}$; No. 391/110, fig. 2, $\mathrm{D}_{1}-\mathrm{D}_{2}$ ). The scales are narrow and elongated, their length varies in the range of $12.0-13.0 \mathrm{~mm}$, width of the scale plate $-4.0-5.0 \mathrm{~mm}$. There is a very strong dorsal 


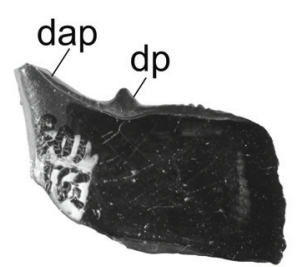

$\mathrm{A}_{1}$

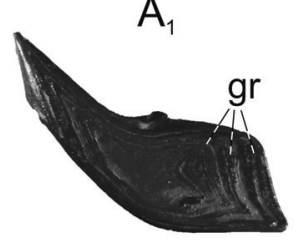

$\mathrm{C}_{1}$

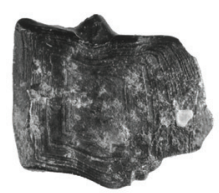

$\mathrm{E}_{1}$

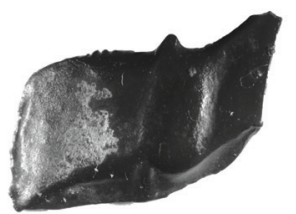

$\mathrm{A}_{2}$

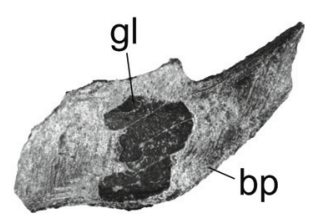

$B_{1}$

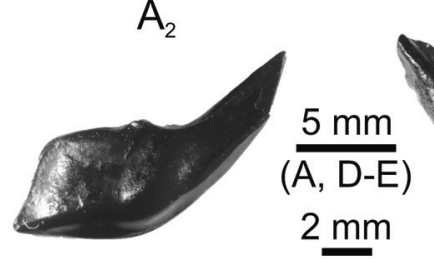

$\mathrm{C}_{2}$

(B-C, F-G)

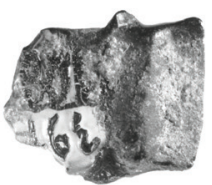

$E_{2}$

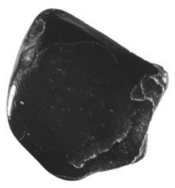

$F_{1}$

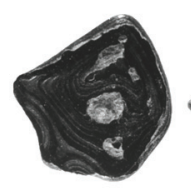

$\mathrm{F}_{2}$

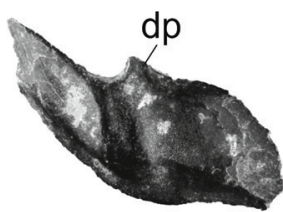

$\mathrm{B}_{2}$

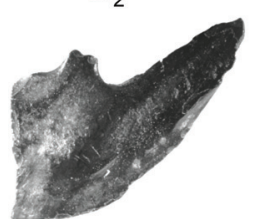

$\mathrm{D}_{2}$

Fig. 2. Ganoid scales of Lepisosteiformes gen. et sp. indet. from Pekari: $A_{1}-A_{2}-$ No. 391/109; $B_{1}-B_{2}-$ No. 391/107a; $C_{1}-C_{2}-$ No. 391/107b; $D_{1}-D_{2}-$ No. 391/110; $E_{1}-E_{2}-$ No. 391/108; $F_{1}-F_{2}-$ No. 391/107d; $G_{1}$ $G_{2}-$ No. 391/107c. Outer view in $A_{1}, B_{1}, C_{1}, D_{1}, E_{1}, F_{1}, G_{1}$, inner view in $A_{2}, B_{2}, C_{2}, D_{2}, E_{2}, F_{2}, G_{2}$. Abbreviations: $b p$, basal plate; $d a p$, dorsal anterior process; $d p$, dorsal peg; $g l$, ganoin layer; gr, ganoin ridges.

anterior process (5.0-8.0 $\mathrm{mm}$ in length) with a widened base and pointed tip. The ventral anterior process is absent as well, and the dorsal peg is comparatively reduced. The latter is located just near the dap base. All the scales are covered with a thin ganoine layer, however the specimen No. 391/107a (fig. 2, $\mathrm{B}_{1}-\mathrm{B}_{2}$ ) partially lacks this cover (due to postmortem redeposition), and therefore its basal plate is uncovered. The scales are the thickest on the vertical of the $d p$. There are two shallow ridges along the margins of the $d a p$, as well as one longitudinal ridge on its outer surface. The posterodorsal edge of all scales is rounded. There is a concave groove starting from the proximal third of the dap up to the posterior half of the $d p$ in specimen No. 391/110 (fig. 2, $\mathrm{D}_{1}-\mathrm{D}_{2}$ ).

Morphotype 3 (specimen No. 391/107c, fig. 2, $\mathrm{G}_{1}-\mathrm{G}_{2}$ ). The small scale (total length $8.5 \mathrm{~mm}$, width $6.0 \mathrm{~mm}$ ) is clearly rhomboidal in shape. Its outer surface is smooth and slightly convex. As other scales in the described series, this specimen is narrower toward the non-serrated edges being the thickest in its central part. The anterior processes are not expressed, and the $d p$ is absent.

Two other scales (No. 391/108, fig. 2, $\mathrm{E}_{1}-\mathrm{E}_{2}$; No. 391/107c, fig. 2, $\mathrm{F}_{1}-\mathrm{F}_{2}$ ) are represented by small rounded and slightly concave fragments with concentric rings on the smooth outer surface, weakly expressed dap and the $d p$.

Com parison. The ganoid scales from Pekari resemble those in representatives of the order Lepisosteiformes in overall morphology, including the presence of two processes forming a rostro-caudal or longitudinal articulation (Cavin et al., 2009) and the reduction of the ventral anterior process diagnostic of the suborder Lepisosteoidei (López-Arbarello, 2012). However, these characters differ from those in the lepisosteiform crown taxa, whose scales have the peg-and-socket vertical articulation reduced or absent in the superfamily Lepisosteoidea and a strong posteriorly directed spine in the suborder Lepisosteoidei (López-Arbarello, 2012; Alvarado-Ortega et al., 2014).

The general shape of some scales from Pekari (morphotypes 2 and 3 ) is similar to the scales of ?Scheenstia sp. described by Sweetman et al. (2014: fig. 13, E-F, p. 891) from the 
Lower Cretaceous deposits of England. Both of them are equal in size and share the same type of articulation. However, the specimens Nos. 391/109, 391/107a, and 391/107b are more elongated and have a stronger dorsal anterior process. Besides, the dorsal edge of the scales in ?Scheenstia sp. is non-serrated, and the scale plate seems to be deeper.

A scale fragment of Scheenstia mantelli from the Late Jurassic of Cherves-de-Cognac in France (Pouech et al., 2015: Fig. 3O) resembles No. 391/107d (fig. 2, $\mathrm{F}_{1}-\mathrm{F}_{2}$ ). Other known scale specimens of Scheenstia (Murray, 2000: Fig. 6B, p. 127; Pouech et al., 2015: Fig. 3R, p. 36; Haddoumi et al., 2016: Fig. 10A, p. 298; Kyselevych \& Kovalchuk, 2019: fig. 2, etc.) share the same morphology and similar ganoin ridges at the outer surface, but have two well-developed anterior processes as well as shorter and deeper scale plate. We can say the same about the scales of Lepidotus figured by Agassiz (1833-1844) and described in detail by Woodward (1919). It should be noted that the morphological differences between Lepidotes and Scheenstia are not completely resolved because not all the known Lepidotes species were considered in the study of López-Arbarello (2012).

The scales of lepisosteiform fishes show significant differences along the trunk of the same individual (see Grande, 2010; López-Arbarello, 2012; Alvarado-Ortega et al., 2014). The attribution of isolated ganoid scales with a certain species (as it was presented by Rogovich, 1861) should be considered with caution because such material often lacks sufficient diagnostic characters. In our case, it is not possible to make an accurate identification and decide whether these scales represent one or two species. We decide to assign the specimens from Pekari as Lepisosteiformes gen. et sp. indet.

\section{Discussion}

The oldest reliable lepisosteiform remains are known from the Lower Toarcian deposits (182 Ma) of Grimmen in Germany (Böhme \& Ilg, 2003). The finding of Lepisosteiformes gen. et sp. indet. in Pekari is the sole Callovian record of this group in Eastern Europe and one of its few occurrences currently known for this age. Another one is Isanichthys latifrons (Woodward, 1893) from the Middle Callovian of Oxford Clay Pit in England (Woodward, 1893), as well as the scales identified as Scheenstia sp. from the Middle Jurassic of Guelb el Ahmar, Morocco (Haddoumi et al., 2016). There is a short report of Callovian fish remains found in Sarykamyshkai 1 (Kyrgyzstan) and assigned to Lepisosteus? sp. (Böhme \& Ilg, 2003), however this record is doubtful (Grande, 2010), and Lepisosteiformes are regarded to be absent in the general faunal list from this locality (Averianov et al., 2005).

As for other Jurassic (but non-Callovian) lepisosteiform occurrences, most of them are known from Europe (Böhme \& Ilg, 2003). Those are remains of Scheenstia laevis (Agassiz, 1833-1844) from the Kimmeridgian/Tithonian of Cerin, Ain and Scheenstia maximus (Wagner, 1863) from Lot-et-Garonne, both in France (Agassiz, 1833-1844; Sauvage, 1902). Swiss record of Jurassic lepisosteiform fossils is represented by teeth and scales of Scheenstia sp. from the Kimmeridgian of Bois de Sylleux and Tchâfoué (López-Arbarello \& Sferco, 2011; López-Arbarello, 2012).

Lepisosteiform fossils, mostly represented by the genus Scheenstia López-Arbarello \& Sferco, 2011, are quite common in lithographic limestones of the Solnhofen and Mörnsheim formations (Late Jurassic) in Germany. Scheenstia maximus (Wagner, 1863) was reported from Eichstätt, Kellheim (Wagner, 1863), and Langenaltheimer Haardt (Böhme \& Ilg, 2003). López-Arbarello \& Sferco (2011) described Scheenstia zappi from the Kimmeridgian of Schamhaupten. Scheenstia decoratus (Wagner, 1863) is known from the Lower Tithonian beds of Solnhofen (López-Arbarello, 2012). Other species of the genus Scheenstia (S. degenhardti (Branco, 1885), S. hauchecornei (Branco, 1887)) were reported from the Upper Berriasian lagoon deposits of Obernkirchen near Bückeburg (Böhme \& Ilg, 2003). 
There are a few Jurassic localities yielding the lepisosteiform remains outside of Europe: Qijiang in China (Tithonian/Kimmeridgian: Beiduyu quijiangensis Murray et al., 2015), Phu Nam Jun in Thailand (Tithonian: Isanichthys palustris Cavin \& Suteethorn, 2006; Thaiichthys buddhabutrensis (Cavin et al., 2003)), and Yosobé near Tlaxiaco in Mexico (Kimmeridgian: Nhanulepisosteus mexicanus Brito, Alvarado-Ortega \& Meunier, 2017).

Every new find of lepisosteiform fossils (even described in open nomenclature) is important for precise reconstruction of the biogeographical history of this group. The revision of old natural history collections is of great interest because it allows re-discovering some valuable but unknown specimens, and describing them in more detail using the newest methodology.

We are thankful to M. Szabó (Hungarian Natural History Museum), E. Hilton (Virginia Institute of Marine Science, College of William \& Mary, USA), and V. Codrea (Babeş-Bolyai University Cluj-Napoca, Romania) for kindly presenting images of lepisosteiform fish scales, reviewing the manuscript and useful suggestions. We express our sincere thanks to Z. Barkaszi (National Museum of Natural History NAS of Ukraine) for proofreading the manuscript, as well as to L. Popova for her comments of stratigraphy.

\section{References}

Agassiz, L. 1833-1844. Recherches sur les Poissons Fossiles. Tome II. Neuchâtel et Soleure, Petitpierre, vi-xii + 1-336.

Alvarado-Ortega, J., Barrientos-Lara, J. I., Espinosa-Arrubarena, L., Melgarejo-Damian, M. del Pilar. 2014. Late Jurassic marine vertebrates from Tlaxiaco, Oaxaca State, southern Mexico. Palaeontologia Electronica, 17.1.24a, 1-25.

Averianov, A. O., Martin, T., Bakirov, A. A. 2005. Pterosaur and dinosaur remains from the Middle Jurassic Balabansai Svita in the northern Fergana Depression, Kyrgyzstan (Central Asia). Palaeontology, 48 (1), 135-155.

Böhme, M., Ilg, A. 2003. fosFARbase, www.wahre-staerke.com.

Branco, W. 1885. Über eine neue Lepidotus-Art aus dem Wealden. Jahrbuch der königlich preussischen geologischen Landesanstalt, 1884, 181-200.

Branco, W. 1887. Beiträge zur Kenntnis der Gattung Lepidotus. I. Die Lepidoten-Fauna des Wealden von Obernkirchen. II. Lepidotus koeneni n. sp. und einige andere jurassische Arten. III. Übersicht über die Arten der Gattung Lepidotus. Abhandlungen zur geologischen specialkarte von Preussen und den thüringischen Staaten, 7 (4), 320-406.

Brito, P. M., Alvarado-Ortega, J., Meunier, F. J. 2017. Earliest known lepisosteoid extends the range of anatomically modern gars to the Late Jurassic. Scientific Reports, 7, 17830.

Cavin, L., Deesri, U., Suteethorn, V. 2009. The Jurassic and Cretaceous bony fish record (Actinopterygii, Dipnoi) from Thailand. In: Buffetaut, E., Cuny, G., Le Loeuff, J., Suteethorn, V., eds. Late Palaeozoic and Mesozoic Continental Ecosystems of SE Asia. Special Publications, Geological Society London, 315, 123-137.

Cavin, L., Suttethorn, V. 2006. A new semionotiform (Actinopterygii, Neopterygii) from Upper Jurassic-Lower Cretaceous deposits of North-East Thailand, with comments on the relationships semionotiforms. Palaeontology, 49 (2), 339-353.

Cavin, L., Suteethorn, V., Khansubha, S., Buffetaut, E., Tong, H. 2003. A new semionotid (Actinopterygii, Neopterygii) from the Late Jurassic-Early Cretaceous of Thailand. Comptes Rendus Palevol, 2, 291-297.

Cope, E. D. 1872. Observations on the systematic relations of the fishes. Proceedings of the American Association for the Advancement of Science, 20, 317-343.

Cope, E. D. 1887. Zittel's Manual of Palaeontology. American Naturalist, 21, 1014-1019.

Garbelli, C., Tintori, A. 2015. A preliminary study on the ornamentation patterns of ganoid scales in some Mesozoic actinopterygian fishes. Bollettino della Società Paleontologica Italiana, 54 (3), 219-228.

Grande, L. 2010. An empirical synthetic pattern study of gars (Lepisosteiformes) and closely related species, based mostly on skeletal anatomy. The resurrection of Holostei. Copeia, 2010 (2A), iii-x + 1-871; supplement.

Gulyaev, D. B. 2015. Ammonites of the genus Bullatimorphites (Tulitidae) from the Lower Callovian of the Kanev dislocation area, central Ukraine. In: Leonova, T. B., Barskov, I. S., Mitta, V. V., eds. Contributions to current cephalopod research: morphology, systematics, evolution, ecology and biostratigraphy. Proceed- 
ing of conference (Moscow, 2-4 April, 2012). Borissiak Paleontological Institute RAS, Moscow, 95-96 [In Russian].

Gulyaev, D. B., Ippolitov, A. P. 2013. Detailed biostratigraphy of the Lower Callovian of the Kanev dislocations area (Cherkassy region, Ukraine). In: Zakharov, V. A., Rogov, M. A., Shurygin, B. N., eds. Jurassic system of Russia: problems of stratigraphy and paleogeography. Fifth all-Russian meeting (September 23-27, 2013), Tyumen', 65-72.

Haddoumi, H., Allain, R., Meslouh, S., Metais, G., Monbaron, M., Pons, D., Rage, J. C., Vullo, R., Zouhri, S., Gheerbrant, E. 2016. Guelb el Ahmar (Bethonian, Anoual Syncline, eastern Morocco): First continental flora and fauna including mammals from the Middle Jurassic of Africa. Gondwana Research, 29 (1), 290-319.

Hay, O. P. 1929. Second Bibliography and Catalogue of the Fossil Vertebrata of North America. Carnegie Institute of Washington Publication, 390, 1-2003.

Kerr, T. 1952. The scales of primitive living actinopterygians. Proceedings of the Zoological Society of London, 122, 55-78.

Kiselev, D. N., Ippolitov, A. P. 2011. New data on Callovian biostratigraphy of Kanev dislocations area. In: Zakharov, V. A., Rogov, M. A., Ippolitov, A. P., eds. Jurassic system of Russia: problems of stratigraphy and paleogeography. Fourth all-Russian meeting (September 26-30, 2011). Saint-Petersburg, 103-106 [In Russian].

Kumar, K., Rana, R. S., Paliwal, B. S. 2005. Osteoglossid and lepisosteid fish remains from the Paleocene Palana Formation, Rajasthan, India. Palaeontology, 48 (6), 1187-1209.

Kyselevych, L., Kovalchuk, O. 2019. The first record of Scheenstia (Actinopterygii, Holostei) from the Late Cretaceous of Ukraine in the context of European occurrence of Mesozoic lepisosteiform fishes. Geo \& Bio, 17, 117-125.

López-Arbarello, A. 2012. Phylogenetic Interrelationships of Ginglymodian Fishes (Actinopterygii: Neopterygii). PLoS ONE, 7 (7), e39370; doi: 10.1371/journal.pone.0039370.

López-Arbarello, A., Sferco, E. 2011. New semionotiform (Actinopterygii, Neopterygii) from the Late Jurassic of Southern Germany. Journal of Systematic Palaeontology, 9, 197-215.

Matlaj, L. M. 2016. Calcareous nannoplankton from Callovian deposits of Kanev's dislocation region. Dopovidi Nacional'noï akademiï nauk Ukraïni, 10, 54-59 [In Ukrainian].

Mönnig, E. 2014. The stratigraphy of the Bathonian-Callovian boundary (Middle Jurassic) in Northern Germany. Neues Jahrbuch für Geologie und Paläontologie Abhandlungen, 274 (2-3), 271-290.

Müller, J. 1844. Ueber den Bau und die Grenzen der Ganoiden und uber das naturliche System der Fische. Bericht uber die zur Bekanntmachung geeigneten Verhandlungen der Akademie der Wissenschaften, Berlin, 1846, 117-216.

Murray, A. M. 2000. The Paleozoic, Mesozoic and Early Cenozoic fishes of Africa. Fish and Fisheries, 1, 111-145.

Murray, A. M., Xing, L., Divay, J., Liu, L., Wang, F. P. 2015. A Late Jurassic freshwater fish (Ginglymodi, Lepisosteiformes) from Qijiang, Chongqing, China. Journal of Vertebrate Paleontology, http://dx.doi.org/10.1 080/02724634.2014.911187.

Nelson, J. S., Grande, T. C., Wilson, M. V. H. 2016. Fishes of the World. $5^{\text {th }}$ ed. John Wiley \& Sons Inc., New York, i-xii + 1-707.

Pouech, J., Mazin, J.-M., Cavin, L., Poyato-Ariza, F. J. 2015. A Berriasian actinopterygian fauna from Chervesde-Cognac, France: Biodiversity and palaeoenvironmental implications. Cretaceous Research, 55, 32-43.

Regan, C. T. 1923. The Skeleton of Lepidosteus, with remarks on the origin and evolution of the lower Neopterygian Fishes. Journal of Zoology, 93 (2), 445-461.

Rogovich, A. S. 1861. On fossil fishes of provinces of the Kiev educational district. Trudy komissii, vysochayshe utverzhdennoy pri Imperatorskom universitete Sv. Vladimira, dlya opisaniya guberniy Kievskogo uchebnogo okruga [Proceedings of the Commission, highly approved at the Imperial University of St. Vladimir, to describe the provinces of the Kiev educational district]. Natural history, 4 (1), 1-87 [In Russian].

Rosen, D. E., Forey, P. L., Gardiner, B. G., Patterson, C. 1981. Lungfishes, tetrapods, paleontology, and plesiomorphy. Bulletin of the American Museum of Natural History, 167 (4), 159-276.

Sauvage, H. E.1902. Recherches sur les vertébrés du Kimméridgien supérieur de Fumel (Lot-et-Garonne). Mémoires de la Socété Géologique de France. Paléontologie, 25, 1-32.

Sweetman, S. C., Goedert, J., Martill, D. M. 2014. A preliminary account of the Lower Cretaceous Wessex Formation (Wealden Group, Barremian) of the Isle of Wight, southern England. Biological Journal of the Linnean Society, 113, 872-896.

Thomson, K. S., McCune, A. 1984. Development of the scales in Lepisosteus as a model for scale formation in fossil fishes. Zoological Journal of the Linnean Society, 82, 73-86.

Tretyak, I. P., Chervonenko, O. V. 2016. A Review of Scientific Collections of the National Museum of Natural History, NAS Ukraine. Proceedings of the National Museum of Natural History, 14, 115-122 [In Ukrainian].

Wagner, J. A. 1863. Monographie der fossilen Fische aus dem lithographischen Schiefern Bayerns. Zweite Abtheilung. Abhandlungen der mathematisch-naturwissenschaftlichen Abtheilung der königlichen bayerischen Akademie der Wissenschaften, 9 (3), 611-748. 
Woodward, A. S. 1893. On the cranial osteology of the Mesozoic ganoid fishes, Lepidotus and Dapedius. Proceedings of the Zoological Society of London, 38, 559-565.

Woodward, A. S. 1919. Genus Lepidotus, Agassiz. In: Carrano, M., ed. The fossil fishes of the English Wealden and Purbeck Formations. Part III. Palaeontological Society, London, 105-148.

Received 22 July 2019

Accepted 25 October 2019 